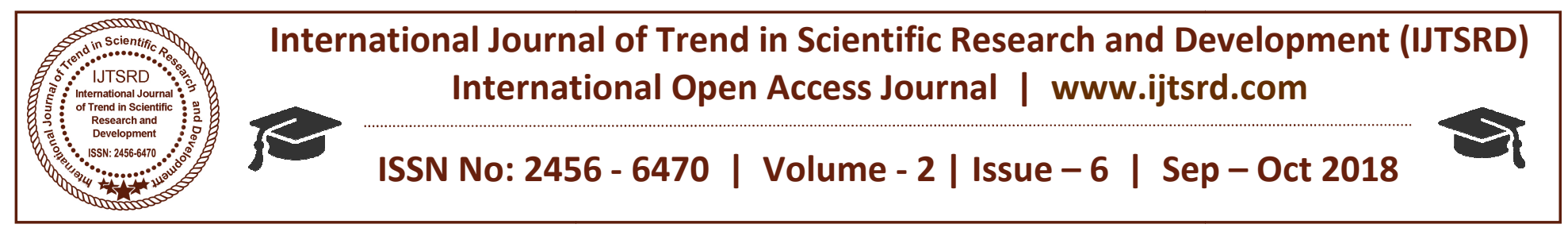

\title{
A Case Study on the Village Keelamattiyan and its Believes
}

\author{
Saswatik Tripathy, Aditi Khan \\ B.Sc. Agriculture Rural and Tribal Development \\ The Dhan-Academy, Tamil Nadu, India
}

\begin{abstract}
The name Keelamattiyan is originated from two Tamil words 'Kila' meaning the lower and 'Mattiyan' means the place. The village is in the southern part of India in the state of Tamin Nadu at Madurai district of Vadipatti block of Melakkal Panchayet. Keelamattiyan (south Indian) is much more developed in compare to the villages of Jharkhand (north Indian), India. But their believes about the casts and superstations are very rigid till now. Cast is a serious issue in the village. Cast believes of the village is one of the barriers in positive growth of the village.
\end{abstract}

The name Keelamattiyan is originated from two Tamil words 'Kila' meaning the lower and 'Mattiyan' means the place. The village is in the southern part of India in the state of Tamin Nadu at Madurai district of Vadipatti block of MelakkalPanchayet. The village was established around the Angalaeshwary temple. According to the villagers the Angalaeshwary was their ancestor who attained the supreme knowledge of the world. He was a sacred soul.Angalaeshwary prayed to God for the villagers so that God don't punish the villagers for the small mistakes God also promise to him that if someone wash his body and confess his guilt to god with a pure mind God will forgive them. The northern boundary of the village is Vaigai River, Pottalaptti village in the south, Melamattayan in the west and the eastern side is upto Kachirairuppu village.

\section{Social Dimension}

CastThere are two DNCs (Denotified Cast) Moopanar and Nayakar. There is also a SC community called Pallar

\section{Gender}

Total Population 1184Male- 605 and Female- 579

Sex ratio 957.02

FamilyMost of the family is joint family but some nuclear families are also there.

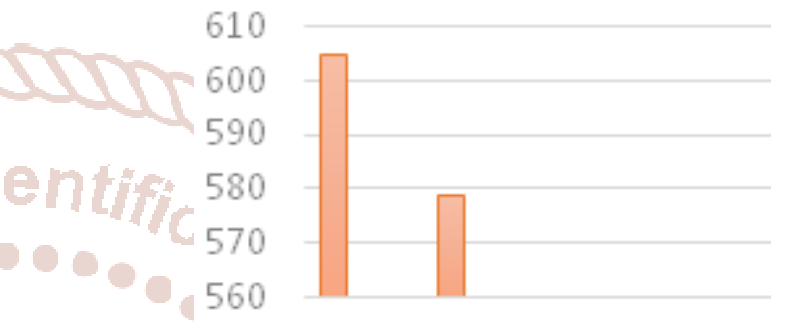

\section{Marriage}

Arrange marriage is common but now a days love marriages are seen in the village. Interacts marriages are strictly prohibited.

Average age of marriage for male is 24-27

Average age of marriage for female is $20-23$

There is culture of dowryand 'Moi'('Moi' is a special south Indian tradition that the guest who attain the marriage functions have to help the family with some money as per their capacity, it is not only about the help, it's about the status.)

\section{Food}

They are mainly vegetarians but occasionally they take non-veg foods. They mainly take mutton on the full moon days

\section{Festivals}

They have many festivals. Pongal, Jalakattu, PortasiPongal, Vaanam, Thookuthal, Rakachumman, PaariVettai- Hunting festival, Kumvabhisekham (Once in 12 years).

\section{Some Beliefs of the villagers}

$>$ They don't wear shoes in the temple premises and inside the villages. 
$>$ They believe that god protect their village from evil powers

$>$ At the time of periods girls have to stay outside of the house for at least 3days.

$>$ If a girl from other village do marriage in this village she have to stay 7 days outside the house after that she can enter the house.

\section{Health dimension}

There is not permanent and regular access to the health centerin the village. A VHN (Village Health Nurse) came twice a week for checkup. One day for the pregnant ladies and one day for the vaccinations. There are three hospitals where the villagers usually go for health facilities Melakkal Govt. Hospital, Solavantham Govt. Hospital and Madurai Govt. Hospital

\section{Seasonal Disease Calendar}

\begin{tabular}{|c|c|c|}
\hline Summer & Rainy & Winter \\
\hline $\begin{array}{c}\text { Diarrhea, } \\
\text { Headache }\end{array}$ & $\begin{array}{c}\text { Diarrhea, } \\
\text { Cholera }\end{array}$ & $\begin{array}{c}\text { Cold, cough fever, } \\
\text { Chicken pox }\end{array}$ \\
\hline
\end{tabular}

\section{Educational Dimension}

In Keelamattiyan an elementary school is situated up to class VIII. After that boys go to Kallar Govt. High School (Higher Secondary) and Millipallum Govt. School (Higher Secondary) and girls go to Solavantham School (Higher Secondary). After 12 they can join KaruMathur college, Muthuramalingam College, Melakkal Polytechnic collage and in Pudhur ITI.

\section{AnganWadi (Child Care)}

Between 0-6 age group there are 61 children. Male41 and female- 20. Among them 56 are in good health but 5 children is not in good health.

\section{Livelihood}

Agriculture is the main occupation of the village, and the livestock rearing (chicks, goat and cow) are common. But as the water availability for the farming is so low they do seasonal migration and work as labour in nearby places, MGNREGA (Mahatma Gandhi National Rural Employment Guarantee Act.100 days job guaranty act.) also provide livelihood to the villagers. Some other livelihoods are wood cutting, shops, police constable, military, nurse, and teacher.

\section{Wages}

Male are getting Rs.300 for 1day and the females getting Rs.150 for 1day.

\section{Natural Resources}

Mainly the agricultural lands which are well mobilized in the village, the ground water level is very low so they use the hill valley as a water shade tank for the rain fed agriculture. The hill Valles are use as the common grazing land.

\section{Infrastructure}

Drinking water is supplied through the pipeline to the village. There is a school in the village, some wells are there which the only source of water areif we put aside the rain. Some bore wells are there which are acquired by them in a subsidized rate from the government the electricity is provided to the bore wells are of free of cost. And in household purposeup to the 100 unit of electric use per month they have to pay the electric bill.

\section{Agriculture}

The soil of the area is sandy so the water holding capacity of the soil is very bad. Ground water level is not so good, whole agriculture is mainly depend on the rain water. Rice needs more water. Only one time rice cultivation is there. But they also cultivate some vegetables and millets.

\section{Seasonal crop calendar}

\begin{tabular}{|c|c|c|}
\hline Rabi & Kharip & Zaid \\
\hline $\begin{array}{l}\text { Tomato, } \\
\text { Chilly, } \\
\text { Brinjal }\end{array}$ & $\begin{array}{l}\text { Paddy, } \\
\text { Okra, Ragi }\end{array}$ & $\begin{array}{l}\text { Cucumber, okra. } \\
\text { Ground nut, Brinjal }\end{array}$ \\
\hline
\end{tabular}

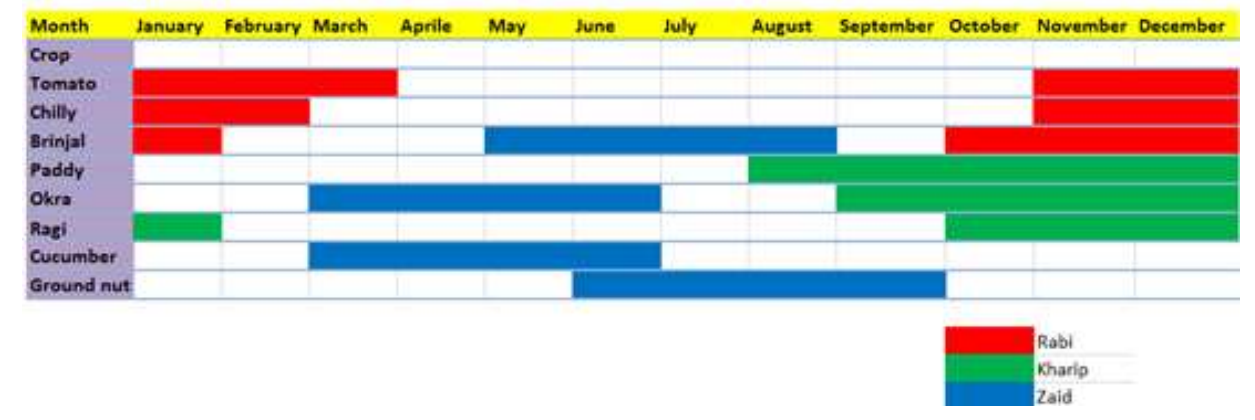


They mainly follow the inorganic farming, but still they are unable to control the pests in their field. There are some banana and coconut orchards in the village but only belongs to the big heads.

\section{Unseen Dimensions}

Keelamattiyan (south Indian) is much more developed in compare to the villages of Jharkhand (north Indian), India. But their believes about the casts and superstations are very rigid till now. Cast is a serious issue in the village. The lower cast people are stayed outside the village they are not allowed to enter in the village temple. Higher cast people don't go to their houses they are not allowed to take water from the same water sources. Not only the adults but the children also make distance with the lower cast kids in the school. The lower cast kids are not allowed to play with the higher one. Wattemani the only kid who know English is from a lower cast and a kid of class $10^{\text {th }}$. As I don't know Tamil I use to take Wattemani with me for translation but as I am with him I am also not allowed into the houses of the higher cast people until I take a bath. The inter cast marriage is strictly prohibited in the village Wattemani'smother Kanimozi was from the higher cast but as she got married with a lower cast man Santharam so they are isolated from the village and now stay outside of the village. Police and Indian Pena code has no role in the village the local leaders taking decision about who is wrong and who is right. Is there is an issue in the village all the villagers gathered into the village common place and the Mukhiya (village head) do the judgment in front of the mob. This is called Panchayet (people's court). In case of Kanimozi and Santharam the Panchayetw as arranged. It was a great offence according to the villagers but Santharam replies that he did this with the permission of God. But the mukhiya want the proof. So the special judgment method was arranged. In this method the suspect have to put his hand in to the boiling butter in front of God and the hand will be covered with clothes for seven days. After seven days if there is no wound then the suspect is innocent and the suspect can claim money to the person who blames him. In case of Santharam he found innocent and claim some land for agriculture to mukhiya because his father already deny him as his son for his sin. Now they are living outside of the village. Kanimozi also told me that at the time of menstruation she had to stay outside of the house may be is a day of scorching sun or a day of heavy rain or freezing winter. If a girl from outside the village got married to this village she has to stay outside of the house for first seven days then the family accept her.

The village is quite developed and more or less everyone have apakka house, every home is electrified, every home has TV (television), some home have refrigerator and grinder. No one is below poverty line. They are carrying more than 800 year's old glory but still stuck into the sluggish mud of classism and superstations. May be they are economically developed but every one of the village is not happy. Some people are still socially deprived and the prevalent social system of the village don't let the deprived one to come up in the social hierarchy. From outside the village is quite happy, clean and prosperous. Someone outside the village who visit for some time also put a status of happy village with the picture of the village, but to understand the real condition we have to stay in the village with the deprived one. My goodness my host was Santharam not the mukhiya otherwise my way of watching the village will be different and I also give the same certificate to the village. Kanimozi was from a higher cast but now in a lower cast but now her husband is rich than her father and leading a happy life with her son and husband. But at the end of the day the social recognition matters more than the money. 